\title{
Parametric Approach to Production Efficiency of Textile Exports in Pakistan
}

\author{
INAYATULLAH KHAN \\ PhD Scholar, Department of Economics, Gomal University, D. I. Khan, Pakistan. \\ Email: inayat66@gmail.com \\ Prof. Dr. MOHAMMAD AFZAL \\ Department of Economics, Preston University, Islamabad -Pakistan. \\ Email:profafzal@gmail.com
}

\begin{abstract}
Pakistan's economy is mainly dependent on textile industry. Textile manufacturers and policy makers are giving priority to improve production efficiency in the textile industry. To compete with rival firms, production efficiency appeared more important than before. This study has analysed the production efficiency of textile manufacturing and exporting firms in Pakistan. The data from annual reports of limited companies registered on the stock exchanges of Pakistan has been used. Cobb-Douglas (half - normal) Stochastic Frontier output model and MLE technique have been applied. Empirical results demonstrate that on average, during the 2016-17, the variable "Cost of material" has the highest elasticity of output (0.719) while the variable "Salaries and wages" has the second larger elasticity of output (0.154). The third input (Energy charges) has elasticity of output 0.096, and the fourth input (Value of operating fixed asset) has the lowest elasticity of output (0.039). The level of production efficiency of the firms in Pakistan ranged from 66.5 percent to 96.73 percent with a mean 89.55 percent during the year. The average estimated value of " $\gamma$ " indicated that majority (approximately 71.95\%) of the variations in the firms 'output were due to difference in technical inefficiency (ui) and small (28.05\%) variations were due to random error (vi).
\end{abstract}

Keywords: Textile Manufacturing and Exporting Firms, Technical Efficiency, Stochastic Frontier Output, MLE Technique, Cobb-Douglas Production Function.

\section{Introduction}

The textile manufacturing sector plays a leading role in developing countries including Pakistan. This sector not only brings the huge amount of foreign exchange, but its basic contribution is to meet the domestic needs for textiles and clothing. Cotton textile and its related items have also a lion - share in total merchandise exports and these provide a strong export base as they constitute the greatest part of the total export goods in some developing countries such as Pakistan. And a strong export base is normally considered a fundamental element of economic development.

Also, from a development point of view, the expanding of textile sector is considered most vital and significant because historically trade in textiles and clothing has been the first stage of the development of industrialization in many countries, often working as the driving force for their economic progress and development (UNCTAD 2008,10). 
The exports of textiles and clothing are often the first major labor-intensive manufactured export items from developing countries and growth of this sector prepares and facilitates the process of change from low income states to quickly industrializing states. These experiences may also be true for Pakistan.

The owners of manufacturing firms are worried about utilizing their resources optimally to ensure maximum profit as well as improving standard of their products so that they could compete successfully with rival firms. If firms are to stay alive, they will have to become more competitive in domestic and international market. Manufacturing firms will have to utilize the available resources more efficiently by taking the advantage of economies of scale than depend on protected trade policies. Many policies were introduced for a firm to remain competitive in the world textile market but increasing production efficiency will count more than ever before. The principal objective of this study is to empirically analyze and explore the production efficiency of textile exporting manufacturing (TEM) firms in Pakistan.

Rest of the paper is structured as follows. Section II provides an overview of the textile industry of Pakistan. Section III reviews the relative literature. Section IV outlines data sources and computation of technical efficiency of a firm. The estimated model, empirical results and the ranking of the firms are presented in section V. Lastly section VI carries conclusion with policy implications and References have been given at the end.

\section{Textile Industry of Pakistan}

Manufacturing sector always plays a crucial role in developing economies. The share of this sector in gross domestic product (GDP) of Pakistan has remained between 13.5 and 13.8 percent for almost last decade. Large scale manufacturing has a big share (about 78 percent) in this sector and has 10.2 percent in the GDP. Textile manufacturing sector has the highest point contribution rate (about 20.9) in large scale manufacturing (GOP 2018-19, 36).

The cotton and cotton textile industry are the main strength of Pakistan's economy. Textile industry is also imperative because of its backward linkages with the basic agriculture sector. Weather and land of Pakistan are suitable for the production of cotton. Currently in cotton production, Pakistan is the fifth largest producer in the whole world and the quality of cotton is also good. Pakistan has also huge potential to further extend the area of cotton cultivation and increase its crop yields. Pakistan comes third, after China and India that consumes the greatest cotton in the whole world.

Pakistan, being the fifth most populated country in the world, has total population 206.6 million and civilian labor force, above 15 years, 65.5 million peoples with unemployment rate $5.79 \%$ in 2017-18. The census 2017 depicted 2.4 percent growth rate in population (GOP 2018-19). Pakistan is among the labor abundant and labor lowest cost countries in the world. Therefore, availability of two important production factors, namely: cotton as basic raw material and low-cost labor force, Pakistan has an additional advantage over all countries in the world except China, India and United States of America. These two abundant factors reduce cost of production which plays a key role in success of export industry.

The textile sector has significance in Pakistan's economy because this is the second largest sector which provides many jobs to women. The Pakistan's textile sector has played vital role in earning foreign exchange and job provision in the economy for over last sixty years. It will continue to play a significant role in growth of the economy as there is no other sector that has the same potential to benefit the economy. Cotton based textiles have over 59 percent share in the total exports; their share in GDP is 8.5 percent. The textile and apparel sector have a contribution of 46 percent in the total manufacturing and has made available jobs to 40 percent of overall industrial sector's workers. This sector has used banking credit more than 40 percent of manufacturing sector and has accounted for almost 25 percent of industrial valueaddition (United Nations \& Commonwealth 2011, 33). Therefore, textile industry is also playing an effective role in poverty reduction. Considering this intrinsic importance, the government of Pakistan 
established a new Ministry for Textile Industry, in 2004 to support export-led growth, as future of the country lies to follow this strategy. Though, in 1960s and 1970s, the government emphasis was on import substitution policies.

After China and India, Pakistan has the greatest spinning capacity in Asia (7.6 percent of overall Asian capacity) and provides five percent in the total world spinning capacity (The PACRA (Pakistan Credit Rating Agency Limited) 2011, 1). Pakistan is one of the major suppliers of cotton yarn and fabric products. The share of these textile items in the world trade is about 30\% and 8\% respectively (Memon 2019, 48). Output of textile industry of Pakistan is dominated by low-value added products. The future potential of world trade in textile is dominated by value added clothing. Cloth exports of Pakistan are about $33 \%$ of its total production and are about $16 \%$ of total textile exports (The PACRA 2019, 12).

The export performance review for five years is depicted in Table 1. It is obvious that the percentage share of textile and clothing industry in total exports has been varying. But it is above 55 per cent.

Table 1: Export Performance of Textiles of Pakistan (US\$ Millions)

\begin{tabular}{|ccccccc|}
\hline & $\begin{array}{c}\text { Cotton \& } \\
\text { Cotton } \\
\text { Textiles }\end{array}$ & $\begin{array}{c}\text { Synthetic } \\
\text { Textiles } \\
\text { Exports }\end{array}$ & $\begin{array}{c}\text { Wool \& } \\
\text { Woolen } \\
\text { Textiles }\end{array}$ & $\begin{array}{c}\text { Total } \\
\text { Textiles } \\
\text { Exports }\end{array}$ & $\begin{array}{l}\text { Pakistan`s } \\
\text { Total Exports }\end{array}$ & $\begin{array}{c}\text { Textile as \% } \\
\text { age of Export }\end{array}$ \\
\hline $2013-14$ & 13349 & 383.47 & 125 & 13857 & 25131 & 55.14 \\
$2014-15$ & 13139 & 330.74 & 119.45 & 13589 & 23885 & 56.90 \\
$2015-16$ & 12168 & 287.79 & 97.68 & 12553 & 20802 & 60.34 \\
$2016-17$ & 12205 & 187.59 & 78.51 & 12529 & 20478 & 61.35 \\
$2017-18$ & 13220 & 309.68 & 75.85 & 13606 & 23222 & 58.59 \\
\hline
\end{tabular}

Source: GOP (various issues)

Exports of Pakistan desperately rely on textile industry that faces many constraints and obstacles at domestic and international level. According to Afzal and Ali (2008) exports have not played a leading role in the economic development of Pakistan except Korean War material boom in 1950s and in May 1972 massive devaluation. Exports registered an extraordinary increase in 1972-73 and 1973-74 and balance of payments showed a surplus but the momentum could not be retained in the following years due to domestic and international factors. Imports have always exceeded exports. To meet Import - Substitution industrialization needs resulted in trade deficit.

They concluded that based on historical experience of Pakistan; there have been Growth-led exports rather than Exports-led growth. Export-led growth policy was adopted in 1990s which did not meet enviable success. Almost 60 percent exports are textile exports. Lack of market access and high energy cost are the major problems of Pakistan exports. Many factors like adverse terms-of-trade, concentration in a few export items and markets, high population growth, exchange rate policy, high inflation, among others reinforced each other to prevent exports from playing a dominant role in economic growth.

This scenario was translated to low efficiency of TEM firms in Pakistan. To compete with rival firms productive efficiency assumes immense importance. Studies in Pakistan as well abroad have addressed exploring the productive efficiency of textile firms, majority using Non-parametric techniques. Keeping in view the dynamic and crucial significance of exports which has prominent impact on macroeconomic stability, the objective, of this study is to explore and analyze the position of production performance by measuring technical efficiency of textile exporting and manufacturing firms in Pakistan.

\section{Review of Literature}

Din, Ghani and Mahmood(2007) estimated the TE (technical efficiency) of 63 large scale manufacturing industries of Pakistan for two years: 1995 - 96 and 2000 - 01. They used the CMI (census of manufactured industries) data for two different empirical techniques: DEA (Data Envelopment analysis) and SF 
(Stochastic Frontier) analysis. In SF analysis technique, they applied Cobb-Douglas specification with four input factors in regressions. Input factors were: capital employed at industry level, number of individuals involved, manufacturing expenses and non - manufacturing expenses at industry level. In this specification, the contribution of industry to GDP (output) was used as the dependent variable. This output has been determined as: value of production of industry - manufacturing expenses of industry and nonmanufacturing expenses of industry. Empirical results showed that all estimated parameters for the year 1995 - 96 were significant at $1 \%$ level.

For the year 2000 - 01, estimated parameter of non-manufacturing expenses was significant at $10 \%$ level and estimated parameter of labor was not statistically significant while other estimated parameters were significant at $1 \%$ level. The value of $\gamma$ was 0.72 for the year 1995-96 and was 0.64 for the year $2000-01$. This indicated that inefficiencies were the large part of the composite error for the two years. Overall, the mean TE of the large-scale manufacturing industries was 0.58 for the year 1995- 96 and it enlarged to 0.65 for the year $2000-01$. The results indicated that majority of industrial group gain TE while some industries decreased their TE level during the periods. The results also indicated that on average, TE level of manufacturing industries was lower in DEA analysis technique. But overall, the ranking of industries remained the same for DEA analysis technique as in SF technique.

Söderbom (2001) estimated TE of not only garments and textiles firms but also firms in food, wood, furniture and metal industry of Ghana, Kenya and Zimbabwe. Cobb - Douglas production function was applied in regressions separately for each country. The independent input factors were capital, employment, education and tenure while the dependent variable was log of value - added. The estimated TE was used as one of independent variables in export participation logit regressions model.

Samad and Patwary (2003) examined the TE of the textile industry of Bangladesh using CMI panel data organized as 12 groups of firms for the period 1988 - 1994. They used gross output as dependent variable and three independent variables were fixed asset, workers and raw material and packaging cost. They estimated average TE as 0.80 .

Baten, Rana, Das and Khaleque (2006) investigated the TE of selected manufacturing industries in Bangladesh and used a SF production function approach based on panel data. A feasible Cobb-Douglas stochastic frontier production function, having time-varying technical inefficiency effects, was estimated. Two alternative distributions were used to model the random inefficiency term: a truncated normal distribution and a half-normal distribution. The estimated average technical efficiency for four groups of industries of Bangladesh over the reference period was $40.22 \%$ of potential output for the truncated normal distribution, whereas it was $55.57 \%$ of potential output for the half-normal distribution.

Bhandari and Maiti (2007) measured the TE of the textile firms of India using cross-sectional data for the years 1985-86, 1990-91, 1995-97, 1998-99 and 2001-02. They used the values of all the products as output. Four other variables used were: 1) the value of inputs including fuel and power, 2) the value of fixed asset, 3) total man-days, and 4) age of the firm in his study. They fitted trans-log output SF analysis model using MLE technique to estimate parameters of the variables. They computed mean TE of the firms ranging from 0.68 to 0.84 during the period.

Sasidaran and Shanmugam (2008) evaluated the overall and input specific TE for 215 firms distributed in six different subs-groups and functioning in the textile industry of India during 1993 - 2006. They used the stochastic coefficients frontier production technique at firm level. They used an unbalanced panel data on output, input factors and other firm specifics qualities obtained from the Capitaline database. For empirical estimation of TE, they followed Cobb - Douglas production function with four input factors. All variables used in the study were in monetary values (Rs. 10 million). The value of manufactured goods (obtained by adding the sales and the variations in the reserves of final goods of the firm) was used as output variable. The variables for factors of production were: 1) remuneration given to workers, 2) cost of material inputs, 
3) charges of energy, 4) the worth of gross fixed assets utilized. The iterative GLS approach was applied for estimation of TE score. Estimated parameters of all four inputs were positive and statistically significant at $1 \%$ level except the energy parameter that is significant at 10 percent level. They found that the overall mean TE is about $54 \%$ and average efficiency levels of the textile firms declined during the period.

Liaquat, Irfan, and Sami (2017) investigated the TE of 75 textile firms in Faisalabad district by applying survey data for the year 2005-06. It was collected by Punjab bureau of statistics. In SF anaylsis technique, they applied trans-log output SF model with three input factors (i.e. labor, intermediate and capital). They used MLE technique to estimate parameters of these variables. The computed TE of the firms was between 0.07 and 0.95 . The mean TE of 75 firms was found 0.81 . The greater numbers (55) of firms were operating with above 80 percent TE level. TE of the firms was significantly affected by Age and size of the firms.

Naz, Khan and Madeeha (2017) examined the productivity performance of the Pakistan's textile manufacturing industry using firm-level panel data for 64 firms for the period 2011-2015. The sources of expansion and compression in output were used for the whole textile industry as well as three sub sectors comprising 35 spinning firms, 21 composite and 8 from weaving textile sector. Empirical results showed that total factor productivity growth of composite, spinning and weaving textile sectors did not show the presence of skewed distribution. The component of technological change had a negative impact on spinning textile sector. TE and technological change had a positive impact on the productivity of composite and weaving textile sectors. Overall, the spinning textile sector had no contribution in the productivity growth.

Xei and Affuso (2017) used SF production function to evaluate the TE of Alabama's agricultural production in the Black Belt mostly populated by African Americans and concluded that TE in the Black Belt was not considerably different from that of the adjacent region. The lower efficiency scores in the two regions suggested a strong potential increase in agricultural production. Government payments were the leading factor associated with wealth effect and capitalization of government payments, particularly in the Black Belt region.

\section{Methodology: Estimation of Production Efficiency of a Firm}

There are different methods and techniques to determine the technical efficiency (TE) at the firm level. In this study, we specified and estimated a SF output model to analyze the TE related to the TEM (Textile Exporting Manufacturing) firms in Pakistan. In production function, economic theory assumes optimizing behavior of producers. The producers show this optimizing behavior either by increasing output and keeping the same inputs or by decreasing inputs and solving the wasting and allocation problems and get the same output. But in all circumstances, all textile producers in Pakistan cannot manage to achieve these goals. Therefore, it is important to look at TE level which producers have achieved.

The ability of a firm to maximize output response for the same combination of input factors used or minimize input factors used to receive the same output response is regarded as TE of the firm. In this study, the researcher analyzed the maximizing output behavior of the TEM firms in Pakistan. Theoretically, for a given level of output, TE is regarded as the empirical estimation level of a specific firm which it succeeded in achieving the best practice production frontier. Therefore, if a firm takes up the "best practice" frontier, it is called as technically efficient. TIE (Technical Inefficiency) level is estimated based on absolute displacement of a specific firm's frontier from the possible (the best practice) production frontier.

This idea has specific importance for textile manufacturing firms as their profit depends on their level of TE. Because those firms which have the same technologies and input quantities will have different levels of output due to different levels of TE. This will generate a larger profit for the more efficient firm although all firms have the same cost of input quantities. 
Aigner, Lovell, and Schmidt (1977) and Meeusen and Broeck (1977) were the first to propose the SF model for production. They also played a considerable role to evaluate TE of firms by this econometric approach. The original specification of a production function with combine error term is specified for cross-sectional data. The SF models have an admirable quality that they do not ascribe all differences from the production frontier to TIE in contrast with other approaches which mix together random error with inefficiency of the firms. Therefore, the SF models provide more consistent estimates. However, the SF models have some weakness. Firstly, these models need some functional specification for the production process. Secondly, these models follow one of the different forms of distribution in inefficiency term $\mathrm{u}_{\mathrm{i}}$. The general statistical model of SF production with some inputs is given below:

$$
\mathrm{OP}_{\mathrm{i}}=\mathrm{b}_{0}+\mathrm{b}_{\mathrm{i}} \mathrm{X}_{\mathrm{i}}+\varepsilon_{\mathrm{i}} \quad \text { and } \quad \varepsilon_{\mathrm{i}}=\mathrm{v}_{\mathrm{i}}-\mathrm{u}_{\mathrm{i}} \quad .(\mathrm{i}=1,2,3 \ldots \mathrm{N})
$$

Where

$$
\begin{aligned}
& \mathrm{OP}_{i}=\text { logarithm of the output of the ith firm, } \mathrm{i}=1,2,3, \ldots \ldots \ldots, 99 \\
& \mathrm{~b}_{0}=\text { Intercept } \\
& \mathrm{X}_{\mathrm{i}}=\text { the input quantities of ith firm } \\
& \mathrm{b}_{\mathrm{i}}=\text { parameters of inputs variables } \\
& \mathrm{N}=\text { the sample size } \\
& \varepsilon_{\mathrm{i}} \text { is a combine stochastic term of two elements, namely } \mathrm{v}_{\mathrm{i}} \text { and } \mathrm{u}_{\mathrm{i}}
\end{aligned}
$$

The $v_{i}$, as in other SF models, is a two - sided normally distributed random error $\left[v_{i} \sim N\left(0, \sigma_{v}^{2}\right)\right]$ that is for random effects in output due to external factors and these are outside the control of a firm (e.g. unusual climate, natural disasters, good fortune, errors in measurement, strikes and variables omitted in the model). While the $u_{i}$ is a firm restricted and one-sided $\left(u_{i} \geq 0\right)$, which measures deviation of the output frontier, due to internal factors, from the best practiced frontier. It represents TIE effects which are behavior factors and can be controlled by a firm. It reflects the managerial capability.

Estimating the TE, output model may have a different shape of distribution for the $u_{i}$. Here $u_{i}$ is distributed independently of $\mathrm{v}_{\mathrm{i}}$. It may have a half normal distribution as suggested by Aigner, Lovell, and Schmidt (1977); Schmidt and Sickles (1984); and Harris (1993) used half-normal and truncated normal distribution while Meeusen and Broeck (1977) are in favor of exponential distribution. Greene (1990) used gamma distribution for the $\mathrm{u}_{\mathrm{i}}$. Using these distributions, output SF can be estimated with MLE (Maximum Likelihood Estimation) technique.

If the input factors are given, the TE of a firm can be determined by maximizing output in terms of the ratio of its mean observed output SF to the mean output SF value when the firm is efficient. A formula for evaluating this TE of a firm estimated from SF output model is given by:

$$
\mathrm{TE}_{\mathrm{i}}=\mathrm{E}\left(\mathrm{OP}_{\mathrm{i}}^{*} \mid \mathrm{u}_{\mathrm{i}}, \mathrm{X}_{\mathrm{i}}\right) / \mathrm{E}\left(\mathrm{OP}_{\mathrm{i}}^{*} * \mathrm{u}_{\mathrm{i}}=0, \mathrm{X}_{\mathrm{i}}\right)
$$

Where $\mathrm{OP}_{\mathrm{i}}{ }^{*}$ denotes the output of the ith firm and is equal to exp $\left(\mathrm{OP}_{\mathrm{i}}\right)$ as the $\mathrm{SF}$ output function and is defined for the logarithm of output (Battese and Coelli, 1988). This is equivalent to the ratio of the

$$
\begin{aligned}
& \mathrm{OP}_{\mathrm{i}}=\exp ^{\mathrm{b} 0+\mathrm{bi} \mathrm{Xi}+\mathrm{vi}-\mathrm{ui}} / \exp ^{\mathrm{b} 0+\mathrm{bi} \mathrm{Xi}+\mathrm{vi}} \\
& \text { After simplification TE is obtained as: } \\
& \mathrm{TE}_{\mathrm{i}}=\exp ^{(\text {-ui })} \quad \mathrm{i}=1,2,3, \ldots \ldots, 99
\end{aligned}
$$

TE can be determined by estimating appropriate functional form of SF output model. TE may have a value between zero and one. It is equal to one only when the firm shows zero TIE effect and the TIE $\left(\mathrm{u}_{\mathrm{i}}\right)$ takes the value zero on the best practiced output frontier. If the firm shows some TIE effect, then TE is less than one and the firm's output is below the best practiced output frontier. 
The analyses of TE of TEM firms in Pakistan, in this study, are based on Cobb-Douglas output function. It is preferred form in empirical research because of its simplicity and as its coefficients directly show the elasticity of output. Wadud (2001) used the same function in his doctoral thesis for estimating TE of textile and clothing manufacturing firms of Australia and Bangladesh. SF output function is specified in terms of inputs at firm level. When the appropriate form of distribution is selected, MLE technique is more efficient estimator (Coelli, Rao and Battese 1998, \& Forsund, Lovell and Schmidt 1980) and that technique is applied in this study to obtain consistent parameter estimates and efficiency scores of SF output function.

\section{Data}

Availability of necessary and relevant data notably in economics is the crux of problem. Textile sector is more challenging because of both in terms of data availability and reliability limitations. The secondary data in this econometric study is used.

The annual reports of overall 126 textile manufacturing companies publicly listed at different stock exchanges from all provinces of Pakistan were collected for the year 2016-17. Textile manufacturing companies, which did not export during the year or did not operate more than six months during the year, were excluded from the study. Only 99 TEM companies were selected for empirical purpose.

The annual reports of TEM companies of Pakistan used in this empirical research were collected from different sources. Mostly of these annual reports were downloaded directly from the several websites of Pakistan TEM companies of Pakistan using internet. Some of these were downloaded from the websites of Karachi stock exchange and for the rest of annual reports, the researcher personally got photo copies of these from Lahore and Islamabad stock exchange.

1. Output, material and energy cost have been calculated after cumbersome addition and subtraction. In this way, it has been tried to minimize the heterogeneity in the different firm's data.

2. The monetary values of all variables used in the model are reported in thousands rupees (Pakistan's currency unit) terms.

Information on employees cannot be obtained from all firms annual reports and subsequently in the econometric model all inputs measures were used in terms of thousand rupees, i.e. instead of employee's man-hours or the number of employees, wages and salaries were used. Battese and Corra (1977); Pitt and Lee (1981); Salim (2006); Jayatilake (2006); Singh, Paramatma and Singh (2007); Sasidaran and Shanmugam (2008); Goplan and Shanmugan(2010); Sheikh and Ahmed (2011); Amornkitvikai and Harvie (2011) have also used cost of labour in their econometric production models. This allows the researchers to control for heterogeneity in labor quality across firms and also avoid inputs heterogeneity as all four variables are in thousands of rupees. This may not be a perfect measure but is one of the alternatives till the times that the employee's man-hours or the number of employees in TEM the firms may be available.

\section{Estimated Model and the Results}

A standard cross-sectional data version of log-linear Cobb-Douglas SF Output Specification is as under:

$$
\mathrm{Ln} \mathrm{OPF}_{\mathrm{i}}=\mathrm{b}_{0}+\mathrm{b}_{1} \ln \mathrm{VOFA}_{\mathrm{i}}+\mathrm{b}_{2} \ln \mathrm{CM}_{\mathrm{i}}+\mathrm{b}_{3} \ln \mathrm{EC}_{\mathrm{i}}+\mathrm{b}_{4} \ln \mathrm{SW}_{\mathrm{i}}+\mathrm{V}_{\mathrm{I}}-\mathrm{U}_{\mathrm{i}} \quad \ldots \ldots \ldots
$$

Where, the character " $\mathrm{i}$ " on the lower level is a symbol of individual firm1, 2, 3 ,

$\ln =$ Natural logarithms

$\mathrm{b}_{0}=$ constant term

$b_{i}=$ Parameter of explanatory variables, subscript i denotes $1,2,3,4$ 
$\mathrm{OPF}=$ Output of the firm $=$ Net Sale + change in finished goods + change in work in process distribution cost - Purchase for resale during the year

VOFA $=$ Value of operating fixed assets

$\mathrm{CM}=$ Cost of Material used

$\mathrm{EC}=$ Energy (fuel, power and water) Charges

$\mathrm{SW}=$ Amount given as salaries, wages and other benefits to labors during the year

$\mathrm{V}=$ Random error

$\mathrm{U}=\mathrm{TIE}$ (Technical Inefficiency)

The likelihood function could be parameterized in terms of $\sigma^{2}=\sigma_{u}{ }^{2}+\sigma_{v}{ }^{2}$ and $\lambda=\sigma_{u} / \sigma_{v}$ (Aigner, Lovell and Schmidt., 1977) or $\gamma=\sigma_{\mathrm{u}}{ }^{2} / \sigma^{2}$ (Battese \& Corra, 1977).

The parameter $\lambda$ may have the value zero or greater than zero depending on the value of $\sigma_{u}$ and $\sigma_{v}$. If the $\lambda$, estimated by MLE method, is statistically significant then SF function is justified (Schmidt \& Lin, 1984). When this $\lambda$ is statistically different from zero i.e. the value of $\sigma_{u}$ is greater than zero, then greater variations in observed output from SF output are due to $u_{i}$ (firm's management practice i.e. TIE rather than $v_{i}$ (random error) and when this $\lambda$ is not different from zero statistically i.e. the value of $\sigma_{u}$ is equal to zero then any variation in the output is due to solely $\mathrm{v}_{\mathrm{i}}$. Therefore, firms functioning on the frontier output are regarded as technically efficient.

The estimated parameter $\gamma$ describes the variations in the total observed output results from SF level of output assigned due to TE (Aignere, Lovell \& Schmidt1977). The parameter $\gamma$ may have the value between 0 and 1 . When $\gamma$ is equal to zero, it shows that all output deviations are due to $v_{i}$ only. If $\gamma$ is equal to one and is statistically significant, it indicates that all deviations from the best practiced frontier are due to inefficiency effects $u_{i}$.

\section{Validity of Specification of Stochastic Frontier Output and Distributional Assumption of $\mathbf{u}_{i}$}

To check whether specification of SF and distribution of $u_{i}$ assumption used in the model are valid or not, a one-sided likelihood ratio test with a mixed $\chi^{2}$ distribution $\left(1 / 2 \chi_{0}^{2}+1 / 2 \chi_{1}^{2}\right)$ proposed by Coelli (1995) is applied. The specification is accepted if $\operatorname{LR}>\chi_{1}^{2}(2 \alpha)$.Also, if the value of $\lambda>0$ and statistically different from zero, then the SF output model used for estimating TE score for individual firm is fitted good and the specification of distributional assumption of $\mathrm{u}_{\mathrm{i}}$ is an appropriate (Schmidt \& Lin, 1984). The computer program STATA was used for estimation of parameters of SF output model given by equation 1 and firm level TE scores of TEM firms of Pakistan.

\section{Efficiency Analysis of the Firms}

The smallest, highest, mean and standard deviation of value of variables OPF (output of the firm), VOFA (value of operating fixed assets), CM (cost of material ), EC (charges of energy ) and SW (salaries and wages of workers) used in assessing the TE of Pakistan's TEM firms for 2016 - 17 are given in Table 2.

From Table 2, it is obvious that standard deviation of all variables has large value than the means of sample of the year which shows that the TEM firms of Pakistan have wide range of operating level of all the variables around their mean. The SF output model given in equation (1) is estimated by MLE and the half normal distributions of $\mathrm{u}_{\mathrm{i}}$ is selected for estimating TE of TEM firms of Pakistan during the year, as for truncated normal distribution of $\mathrm{u}_{\mathrm{i}}$, the data was not converged i.e. STATA did not show the results. 
Table 2: Standard Deviation of Variables Used in Estimation

Number of firms $=99$ (Values are in Rs. Thousands)

\begin{tabular}{|ccccc|}
\hline Variable & Smallest & Highest & Mean & Standard deviation \\
OPF & 130,306 & $19,555,873$ & $3,051,597$ & $3,441,377$ \\
VOFA & 17,073 & $12,008,704$ & $1,638,347$ & $1,957,891$ \\
CM & 71,486 & $14,199,396$ & $2,124,592$ & $2,299,772$ \\
EC & 4,322 & $1,836,638$ & 246,157 & 286,619 \\
SW & 4,313 & $1,478,642$ & 204,381 & 26,487 \\
\hline
\end{tabular}

Source: Author Computation

The estimated parameters of the variables along with standard error, $\mathrm{z}$ - score, $\mathrm{p}$ - values and confidence interval of the model were presented in Table 3. The software did show $\mathrm{z}-$ scores and $\mathrm{p}-$ values of the error terms, $\sigma^{2}$ and $\lambda$. Therefore, these values were not shown in Table 3. The likelihood ratio test of $u_{i}$ presented the value of 2.58 (significant at 0.05). All estimated parameters of dependent variables have expected positive sign and are significant at $1 \%$ level except VOFA which is significant at $10 \%$ level. This indicated that the use of SF approach in regression was acceptable. Therefore, the model used, and the specification of distributional assumption were appropriate. So, the model was an adequate for estimating TE score for TEM firms of Pakistan.

The null hypothesis $\mathrm{H}_{0}: \lambda=0$ or $\mathrm{H}_{0}: \gamma=0$ specifies that the firms are fully technically efficient in stochastic output frontier model. This implies that $\sigma_{\mathrm{u}}$ is zero. Therefore, $\mathrm{u}_{\mathrm{i}}$ is zero; then we can consistently determine the parameters of the specified model by employing OLS (ordinary least squares). But here the value of $\lambda>$ 0 i.e. $\lambda=1.60$ and statistically different from zero. So, this hypothesis is rejected for our data.

Table 3: The Results of Cobb-Douglas Model: 2016-17

Dependent Variable is OPF (output of a firm) Number of observations $=99$

Log likelihood function $=66.6863 \quad$ Number of iterations $=03$

\begin{tabular}{|ccccccc|}
\hline Variables & $\begin{array}{c}\text { Estimated } \\
\text { Parameters }\end{array}$ & $\begin{array}{c}\text { Standard } \\
\text { Deviations }\end{array}$ & Z- scores & $\begin{array}{c}\mathrm{p}- \\
\text { values }\end{array}$ & $95 \%$ CI \\
\hline Intercept & 0.9347 & 0.1904 & 4.91 & 0.000 & 0.5615 & 1.3079 \\
VOFA & 0.0393 & 0.0233 & 1.68 & 0.092 & -0.0064 & 0.0849 \\
$\mathrm{CM}$ & 0.7187 & 0.0280 & 25.70 & 0.000 & 0.6639 & 0.7735 \\
$\mathrm{EC}$ & 0.0957 & 0.0243 & 3.94 & 0.001 & 0.0481 & 0.1433 \\
$\mathrm{SW}$ & 0.1541 & 0.0312 & 4.93 & 0.000 & 0.0928 & 0.2153 \\
$\sigma_{\mathrm{v}}$ & 0.0896 & 0.0177 & & & 0.0609 & 0.1321 \\
$\sigma_{\mathrm{u}}$ & 0.1437 & 0.0350 & & & 0.0891 & 0.2316 \\
$\sigma^{2}$ & 0.0287 & 0.0079 & & & 0.0133 & 0.0440 \\
$\lambda$ & 1.6027 & 0.0501 & & & 1.5045 & 1.7008 \\
\hline
\end{tabular}

Source: Author Computation

L-R test of $\sigma_{u}=0 ; \quad \chi^{2}(01)=2.58, \quad$ Prob $>=\chi^{2}=0.054$

Further the empirical results of the model showed that CM (cost of material) had the greatest elasticity of output than other inputs i.e. 0.719.It means that one-unit change in the cost of material resulted in 0.719unit change in the total textile output, keeping other inputs constant at their mean level. SW (salaries and wages) had the second maximum elasticity of output i.e. 0.154.It implies that one-unit change in the salaries and wages resulted in 0.154-unit change in the total textile outputs, keeping other factors of output constant at their average level. 
Table 4: Grading of Pakistan's TEM Firms: 2016-17

\begin{tabular}{|c|c|c|c|c|c|}
\hline \multicolumn{6}{|c|}{ Table 4 (a) } \\
\hline Grade & & $\mathrm{TE}_{\mathrm{i}}$ & Grade & Firm No. & $\mathrm{TE}_{\mathrm{i}}$ \\
\hline 1 & 33 & 0.9673 & 47 & 65 & 0.912 \\
\hline 2 & 95 & 0.9627 & 48 & 92 & 0.9116 \\
\hline 3 & 44 & 0.9625 & 49 & 82 & 0.911 \\
\hline 4 & 63 & 0.9617 & 50 & 69 & 0.9091 \\
\hline 5 & 75 & 0.9601 & 51 & 72 & 0.909 \\
\hline 6 & 57 & 0.9599 & 52 & 30 & 0.9084 \\
\hline 7 & 5 & 0.9587 & 53 & 83 & 0.9076 \\
\hline 8 & 7 & 0.9584 & 54 & 1 & 0.9075 \\
\hline 9 & 99 & 0.9576 & 55 & 47 & 0.9071 \\
\hline 10 & 25 & 0.9553 & 56 & 4 & 0.9028 \\
\hline 11 & 42 & 0.954 & 57 & 52 & 0.9024 \\
\hline 12 & 74 & 0.9536 & 58 & 55 & 0.9015 \\
\hline 13 & 10 & 0.9505 & 59 & 29 & 0.9008 \\
\hline 14 & 94 & 0.9443 & 60 & 61 & 0.8977 \\
\hline 15 & 96 & 0.9423 & 61 & 22 & 0.8967 \\
\hline 16 & 6 & 0.9397 & 62 & 16 & 0.8961 \\
\hline 17 & 13 & 0.938 & 63 & 28 & 0.8956 \\
\hline 18 & 37 & 0.9377 & 64 & 89 & 0.8911 \\
\hline 19 & 86 & 0.9373 & 65 & 31 & 0.8879 \\
\hline 20 & 34 & 0.9347 & 66 & 78 & 0.8871 \\
\hline $21=$ & 70 & 0.9344 & 67 & 26 & 0.8863 \\
\hline 22 & 54 & 0.934 & 68 & 45 & 0.8851 \\
\hline 23 & 56 & 0.932 & 69 & 32 & 0.8843 \\
\hline 24 & 90 & 0.9277 & 70 & 40 & 0.8841 \\
\hline 25 & 50 & 0.9275 & 71 & 51 & 0.8815 \\
\hline 26 & 81 & 0.927 & 72 & 97 & 0.8786 \\
\hline 27 & 23 & 0.9264 & 73 & 68 & 0.8774 \\
\hline 28 & 66 & 0.9242 & 74 & 84 & 0.8761 \\
\hline 29 & 15 & 0.9241 & 75 & 77 & 0.8714 \\
\hline 30 & 91 & 0.9236 & 76 & 87 & 0.8624 \\
\hline 31 & 27 & 0.923 & 77 & 20 & 0.862 \\
\hline 32 & 35 & 0.9229 & 78 & 18 & 0.8617 \\
\hline 33 & 2 & 0.9229 & 79 & 14 & 0.8617 \\
\hline 34 & 53 & 0.9217 & 80 & 76 & 0.859 \\
\hline 35 & 39 & 0.921 & 81 & 17 & 0.8575 \\
\hline 36 & 98 & 0.9206 & 82 & 49 & 0.8553 \\
\hline 37 & 67 & 0.9197 & 83 & 73 & 0.8543 \\
\hline 38 & 24 & 0.9191 & 84 & 19 & 0.8539 \\
\hline 39 & 38 & 0.9191 & 85 & 12 & 0.8441 \\
\hline 40 & 71 & 0.9186 & 86 & 9 & 0.8422 \\
\hline 41 & 11 & 0.9186 & 87 & 41 & 0.8377 \\
\hline 42 & 62 & 0.9181 & 88 & 43 & 0.8347 \\
\hline 43 & 59 & 0.9165 & 89 & 46 & 0.8213 \\
\hline 44 & 93 & 0.9156 & 90 & 3 & 0.8191 \\
\hline 45 & 80 & 0.9131 & 91 & 48 & 0.8187 \\
\hline 46 & 8 & 0.9125 & 92 & 85 & 0.8143 \\
\hline
\end{tabular}


Table 4 (b)

\begin{tabular}{|cccccc|}
\hline Grade & Firms' No. & TE $_{\mathrm{i}}$ & Grade & Firms' No. & TE $_{\mathrm{i}}$ \\
\hline 93 & 21 & 0.7861 & 97 & 79 & 0.7682 \\
94 & 64 & 0.7842 & 98 & 88 & 0.7485 \\
95 & 58 & 0.7806 & 99 & 36 & 0.665 \\
96 & 60 & 0.7778 & & \\
& & Mean TE $=0.8955$ & \\
\end{tabular}

Source: Author Computation

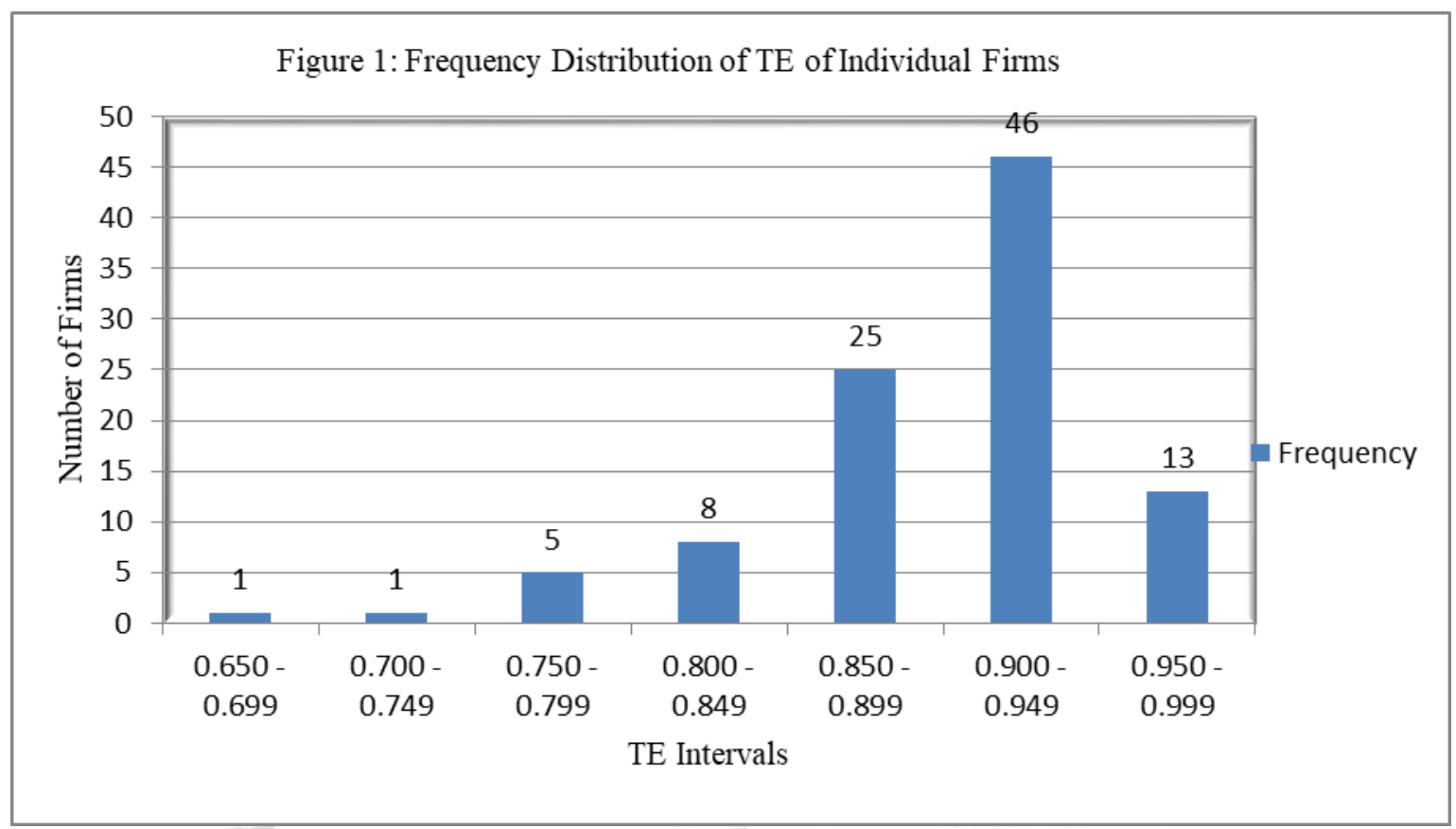

Source: Table 4

And EC (energy charges) has the third largest elasticity of output i.e. 0.096 (this support and validates the neo classical theory which stress that energy is also the factor of production).It means for everyone unit change in the charges of fuel and power; output changed by 0.096 units, keeping other factors of output constant at their mean level. The empirical results of the model show that VOFA has the lowest elasticity of output than other inputs i.e. 0.0393 which describes that for everyone unit change in the value of operating fixed asset, output changed by 0.0393 unit, keeping other components of output constant at their mean position. This describes that fixed capital (sunk cost) play minimum role in TEM firms in Pakistan.

The value of " $\gamma$ " was calculated by $\sigma_{\mathrm{u}}{ }^{2} / \sigma^{2}$ and was found 0.7198 which indicated that majority (approximately 71.95\%) of the stochastic variations in TEM firms' output during 2016 - 17 could be assigned to difference in TIE in production process and small $(28.05 \%)$ variations could be assigned to random error $\left(\mathrm{v}_{\mathrm{i}}\right)$. As observed in the above results, the elasticity of all the inputs was inelastic and the sum of coefficients was 1.0076. It revealed that TEM firms had achieved constant returns to scale during the year.

The firm-specific efficiencies of TEM firms were shown in Table 4 and FD of the same was shown in Table 5. A firm having highest level of TE was ranked one and having score below away from this level represented lower ranking in production efficiency. 
Table 5: Frequency Distribution of TE for Individual Firms: 2016 - 17

\begin{tabular}{|cc|}
\hline \multicolumn{3}{|c|}{ Number of firms $=99$} \\
\hline $0.650-0.699$ & Frequency \\
$0.700-0.749$ & 01 \\
$0.750-0.799$ & 01 \\
$0.800-0.849$ & 05 \\
$0.850-0.899$ & 08 \\
$0.900-0.949$ & 25 \\
$0.950-0.999$ & 46 \\
Min. TE & 13 \\
Max. TE & 0.6650 \\
Average TE & 0.9673 \\
\hline
\end{tabular}

${ }^{\mathrm{I}}$ TEnear to one shows greater TE

Source: Table 4

Mean TE score of TEM firms of Pakistan is 0.8955. It shows that on average the firm, if it has comparable inputs, is obtaining 89.55 percent of the output that is possible for a best practiced firm during the year. Technical efficiencies of the firms are between 66.50 per cent and 96.73 per cent. In the Figure 1, frequency distribution of TE of the firms indicates that maximum number of firms (46 out of 99) have TE score in interval 0.90 to 0.95 while only 07 firms have TE score in intervals less than 0.80 .

\section{Conclusions}

Cobb-Douglas SF output Model with half-normal distribution of $u_{i}$ (as for truncated normal distribution of $\mathrm{u}_{\mathrm{i}}$, the data was not converged in STATA) indicates that on average CM (cost of material) has the greatest elasticity of production (i.e. 0.721) than other inputs during the year 2016 - 17. This implies that material used input is playing a major role in textiles output of TEM firms in Pakistan. The second important input is SW (Salaries, wages and other benefits) which has the elasticity of output i.e. on average 0.157 during the period. These two inputs are abundant in Pakistan and this validates the endowment factors theory of international trade. EC (energy and fuel charges) has the third largest elasticity of output i.e. on average 0.080. This support and validates the neo classical theory which stresses that energy is also the factor of production). VOFA (value of operating fixed asset) has the lowest elasticity of output than other inputs i.e. on average 0.048 . This describes that fixed capital (sunk cost) play minimum role in textiles output of TEM firms in Pakistan.

The results of MLE show that elasticity of all the inputs are inelastic i.e. a one percent increase in each input results in a less than one percent increase in output. The sum of coefficients is almost 1.00; it reveals that the firms have maintained constant returns to scale which is the main objective of a firm. So, the TEM firms of Pakistan are scale efficient during the year.

The level of TE of Pakistan's TEM firms is ranged on average from $66.50 \%$ to $96.73 \%$ with a mean 89.55 $\%$ during the period. It is inferred that the firms are not achieving 100 percent of potential production. This implies that in the firms, there is potential to increase output if available resources are used more efficiently. Therefore, on average, in the short run, output of the firms can be increased by at least $10.45 \%$ by employing the most efficient methods and procedures as applied by the best practiced TEM firms of Pakistan.

The mean TE of individual firms remain near to maximum TE which describes that maximum number of firms have their $\mathrm{TE}_{\mathrm{i}}$ score high and closer to maximum $\mathrm{TE}_{\mathrm{i}}$ score and very few firms have low $\mathrm{TE}$ score and closer to minimum TE score. It is proven fact that as country makes progress; the inefficiencies of 
firms are generally inclined to disappear since the market forces drive the inefficient firm out of the business.

The average estimated value of $\gamma$ indicates that majority (approximately $71.95 \%$ ) of the variations in the firms' output are due to difference in $\operatorname{TIE}_{\mathrm{i}}\left(\mathrm{u}_{\mathrm{i}}\right)$ and small $(28.05 \%)$ variations are due to random error $\left(\mathrm{v}_{\mathrm{i}}\right)$.

\section{Policy Implications}

1- This study has found out that the material cost and labour cost have major role in output of the firms. So, material and labour cost should be targeted in increasing output of the firms. Also, as the TEM firms are operating on constant return to scale and elasticity of output with respect to all inputs are inelastic therefore, policy implication is to increase output of the firms, policy makers should encourage the TEM firms to increase the variable inputs and invest in new plants in other districts where material and labour are easily available.

2- There is potential to enhance efficiency of Pakistan's TEM firms. On average and at least $10.26 \%$ increase in output can be achieved by employing the most efficient methods and procedures. Textile industry of Pakistan is cotton based and the industry used more cotton than produce in the country. The material cost, according results of the study, accounted for almost $72 \%$ of inputs. When demands for exports increased, the firms might import the inputs material. Therefore, policy implication is that to increase production and hence exports of the firms, policy makers should timely revised production and import policies to facilitate the management of TEM firms in Pakistan to get quick access to the supply of cheap and best quality input factors especially cotton.

\section{References}

Afzal, M \& Ali,K. (2008). A historical evaluation of export-led growth policy in Pakistan. Lahore Journal of Policy Studies, 2(1), 69-82.

Aigner, D. J., Lovell, C. A. \& Schmidt, P. (1977). Formulation and estimation of stochastic frontier production function models.Journal of Econometrics, 6 (1), 21-37.

Amornkitvikai, Y. \& Harvie, C. (2011). Finance, ownership, executive remuneration and technical efficiency: a stochastic frontier analysis (SFA) of Thai listed manufacturing enterprises. Australian Accounting Business and Finance Journal, 5(1), 35-55.

Baten, Azizul, Masud Rana, Sumonkanti Das \& Abdul Khaleque (2006). Technical efficiency of some selected manufacturing industries in Bangladesh: A stochastic frontier analysis. The Lahore journal of economics. 11(2), 23-41.

Battese, G.E. and Coelli, T. J. (1988). Prediction of Firm Level Technical Efficiencies with a Generalized Frontier Production Function and Panel Data, Journal of Econometrics, 38(3), 387-99.

Battese, G.E. \& Corra, G.S. (1977). Estimation of a production frontier model: With application to the pastoral zone of Eastern Australia. Australian Journal of Agricultural Economics, 21(3), 169-179.

Bhandari, A. K.\& Maiti, P. (2007). Efficiency of Indian manufacturing firms: Textile Industry as a Case Study. International Journal of Business and Economics, 6 (1), 71 - 88.

Cobb, C. W. \& Douglas, P. H. (1928). A theory of production. American Economic Review 18(1), 139-165.

Coelli, T. J. (1995). Estimators and hypothesis tests for a stochastic frontier function: A Monte Carlo Analysis. Journal of Productivity Analysis 6, 247 - 68.

Coelli, T. J., Rao, D. S. \& Battese G. E. (1998). An Introduction to Efficiency and Productivity Analysis, Kluwer Academic Publishers.

Din, M., Ghani, E. \& Mahmood, T. (2007). Pakistan's manufacturing sector: A stochastic frontier and data envelopment analysis. The Pakistan Development Review, 46(1), 1- 18.

Forsund, F. R., Lovell, C. A. \& Peter, Schmidt (1980). A survey of frontier production functions and their relationship to efficiency measurement. Journal of Econometrics, 13 (1), 5 - 25.

Goplan, S., \& Shanmugan, K.R. (2010). The multi-fibre agreement phase-out: Efficiency implications of textile firms in India, Trade and Development Review, 3(1), 59-75 
Government of Pakistan. Pakistan Economic Survey (various issues). Islamabad, ministry of finance, economic advisor wing.

Greene, W. H. (1990). A Gamma-Distributed Stochastic Frontier Model, Journal of Econometrics, 46, 141 163.

Harris, R.I.D. (1993). Measuring efficiency in New Zealand manufacturing in 1986/87 using a frontier production function approach. New Zealand Economic Papers, 27, 57-79

Jayatilake, J.C.R (2006). The estimation of technical efficiency of tea manufacturing firms in srilanka; a stochastic frontier analysis, Annual Research Journal of SLSAJ, 6, 90-94

Liaquat, H., Irfan, A. \& Sami, A. (2017). Technical efficiency and its determinants: A case study of Faisalabad textile industry, City University Research Journal, Special Issue: AIC, Malaysia, 183- 194

Meeusen, W. \& Broeck J. V. (1977). Efficiency estimation from Cobb-Douglas production functions with composed errors, International Economic Review, 18 (2), 435- 444.

Memon, N. A. (2019). Pakistani textile industry still facing problems. Pakistan Textile Journal, 2, 48-50

Naz, F., Khan, H. \& Madeeha, S. (2017). Productivity and efficiency analysis of Pakistani textile industry using malmquist productivity index approach, Journal of Management and Research (JMR),4(2),65-87

Pitt, M. M., \& Lee, L-F (1981). The measurement and sources of technical inefficiency in the Indonesian weaving industry. Journal of Development Economics, 9 (1), 43-64.

Salim, R. A. (2006). Measuring Productive efficiency incorporating firms' heterogeneity: An empirical analysis. Journal of Economic Development, 31(1).

Samad, Q. A., \& Patwary, F. K. (2003). Technical efficiency in the textile industry of Bangladesh: An application of frontier production function. Information and Management Sciences, 14(1), 19-30.

Sasidaran G., \& Shanmugam, K. R. (2008). Impact of trade liberalization on the efficiency of textile firms in India, ISAS (Institute of South Asian Studies), National University of Singapore, Working Paper No. 52.

Schmidt, P. \& Lin, T. (1984). Simple tests of alternative specifications in stochastic frontier models. Journal of Econometrics, 24(3), 349-361

Schmidt, P. \& Sickles, R. C. (1984). Production Frontier and Penal Data. Journal of Business and Economic Statistics, 2(4), 367-374

Sheikh, S. A. \& Ahmed, S. (2011). Impact of trade liberalization and domestic economic reforms on technical efficiency of agro-based industries in Pakistan; International Journal of Business and Social Science, 2(23)

Singh, N.P., Paramatma, S., \& Singh, R.P. (2007). Research note, sugar industry in UttarPradesh: efficiency still holds the key. Agricultural Economics Research Review; 20, 157-170

Söderbom, Måns (2001). What drives manufacturing exports in Africa? Evidence from Ghana, Kenya and Zimbabwe, Csae-Unido. Working Paper No. 2

The PACRA (Pakistan Credit Rating Agency Limited) (2011). Textile sector study, Retrieved from Www.pacra.com

The PACRA (Pakistan Credit Rating Agency Limited) (2019). Weaving - An overview, Retrieved from www.pacra.com

UNCTAD (2008). Training module on trade in textiles and clothing, the post-atc context, United Nations conference on trade and development (UNCTAD). New York United Nations Publication, New York and Geneva, ISSN 1816-5540

United Nations and Commonwealth (2011). Potential supply chain in textiles and clothing sector in South Asia: An explanatory study. United Nations and Commonwealth Secretariat, 2011, ditctncd2011d3_en.pdf

Wadud, I. K. (2001). Trade arrangements, productivity growth and firm level technical efficiency in textile and clothing industries of Australia and Bangladesh 1972 - 1998, Doctor of Philosophy Thesis, department of economics, university of Wollongong, Retrieved from http. / / ro.uow. edu.au / theses / 1328

Xie, Zhang, \& Ermanno Affuso (2017). An efficiency and productivity analysis of the agricultural sector in Alabama. International Journal of Applied Economics, 14(2), 19-36. 